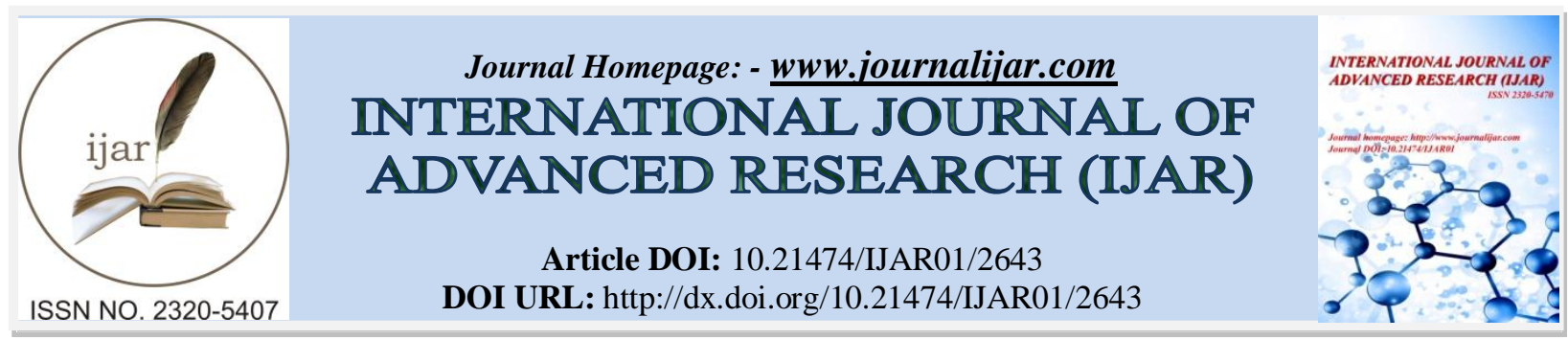

\title{
RESEARCH ARTICLE \\ HISTOPATHOLOGICAL CHANGES IN THE SPLEEN OF CYPRINUS CARPIO ON ACUTE EXPOSURE OF COPPER SULPHATE.
}

Dr Sabiha Kamaal Khan.

\section{Manuscript Info}

Manuscript History

Received: 30 October 2016

Final Accepted: 29 November 2016

Published: December 2016.

Key words:-

Cyprinus carpio,spleen, $\mathrm{CuSO}_{4}$,

histopathology.

\section{Abstract}

The present study was carried out to determine the effect of copper sulphate on histopathological changes in Cyprinus carpio. Copper sulphate is mainly used as herbicide and also used as fungicide in fish farming to control fungal diseases of the fish. It is also a main constituent in industrial effluent of electrical and power generation plants which directly enters into water bodies and hit non target aquatic organisms specially fishes. To assess the toxicity of $\mathrm{CuSo}_{4}$ three sublethal concentrations of $\mathrm{LC}_{50}$ value were taken and fishes were exposed to them for $96 \mathrm{hrs}$.

Marked histopathological changes were observed in the spleen exposed to different sublethal concentrations of $\mathrm{CuSo}_{4}$ and the severity of damage increased with the increasing concentrations of $\mathrm{CuSo}_{4}$. Hepatocytes showed vacuolization, necrosis and the nucleus becomes less prominent and outer capsule also seen ruptured. These findings represent toxicity of Copper Sulphate on Cyprinus carpio specifically its spleen.

Copy Right, IJAR, 2016,. All rights reserved.

\section{Introduction:-}

Most of the important and large rivers of India in particular and world in general are highly polluted and presently are the most exploited natural system. With the growth of industrialization many toxic and harmful substances affect the non target organisms and cause pathological changes. Singh et al.(1990) studied environmental pollution and its effect on aquatic organisms. Srivastava et al. (1982) reported the hisotopathological changes and accumulation potential in the fish tissues under chromium stress. The presence of heavy metals, pesticides,other harmful chemicals, liquid wastes and even half burnt bodies in India are producing deleterious effect on the various biological systems of the organisms living in the water specially lymphatic system. Histopathological studies have long been recognized to be biomarkers of stress in fish (Van der Oost, Beyer, \& Vermeulen, 2003).

A wealth of literature is available on the lymphatic system of mammals but its study in fishes has far escaped the interest of investigators. The effect of toxic substances on the spleen of fishes has not been worked out in detail. Although some investigators like Raibeemol and Chitra (2015) reported histopathological alterations in gills, liver, kidney and spleen of fishes, Etrophus maculatus due to the acute exposure of chlorpyrifos.

Some metals are non biodegradable and their presence in food chain may be the reason for bioaccumulation in different organs of animals as well as in humans (Saad et al., 2012). The effect of heavy metals on activity and enzyme kinetics on AChE of alimentary canal of Cyprinus carpio has been worked out by Tembhre and kumar (1995). They observed the effect of copper sulphate on AChE system in the alimentary canal and also noticed many 
histopathological changes in the various parts of alimentary canal. On reviewing the literature one is stuck that very little work has been carried out on the histopathology of the spleen of Cyprinus carpio.

In the present study attention has been paid on the histopathology of spleen caused due to the acute exposure of Copper Sulphate.

\section{Methodology:-}

Healthy living specimens of Cyprinus carpio weighing $12 \pm 0.5 \mathrm{gm}$ and $12 \pm 2 \mathrm{~cm}$ in length have been brought from Patra fish farm, Bhopal . They were brought to the laboratory in well-aerated containers, to avoid any physical injuries and stress to the fish.

The fishes were then screened for any pathological conditions and washed with $1 \% \mathrm{KMnO}_{4}$ solution. The healthy specimens were then transferred to glass aquaria $(60 \times 30 \times 30 \mathrm{~cm})$ containing tap water. The fishes were acclimatized to the laboratory conditions for almost 15 days prior to the experimentation. Fishes were fed with artificial fish food during the period of acclimatization and feeding was stopped $24 \mathrm{hrs}$ prior to acute exposure of $\mathrm{CuSO}_{4}$; water was replaced daily by siphoning to remove waste material and debris to prevent water from being polluted. The Physicochemical characteristics of the water were analysed as per the procedure of (APHA, 1995), American public health association.

Copper Sulphate was obtained from Ranbaxy laboratories ltd.,India. It was a blue coloured crystalline solid with molecular weight of 159 and was soluble in water. $\mathrm{LC}_{50}$ of $\mathrm{CuSo}_{4}$ is based on the value given by Tembhre and Kumar(1995). It was $0.12 \mathrm{mg} / \mathrm{l}$.In the present study $1 / 10,1 / 15$, and $1 / 20$ of the $96 \mathrm{hrs} \mathrm{LC}_{50}$ were selected as sub lethal concentration and the fishes were exposed to each concentration for 96hrs. Eight number of fishes were kept in aquaria for each toxicity test. A control batch corresponding to each test group was also maintained simultaneously.

The experiments were repeated three times. Fishes were taken out, blotted dry with soft absorbent paper and dissected to remove spleen which was then rinsed in physiological saline solution to remove debris etc. Spleens were fixed in Bouin's solution for $24 \mathrm{hrs}$ followed by thorough washing in $70 \%$ alcohol and were kept in 90\%alcohol for overnight. The blocks were prepared according to the paraffin embedding process. Serial sections were cut 7 to 15 microns thick and ribbons were stretched on cleaned slides using Mayor's albumin. The sections were stained with Haematoxylin and Eosin. Microphotographs were taken by Olympus microphotograph equipment.

\section{Results and Discussions:- \\ Histology:-}

Fishes are the first vertebrates to have spleen. According to Roberts (2001), spleen is the only lymph-node organ in teleost fish. It is externally covered by a capsule which is lined by a layer of cells. Spleen shows presence of reticulocyte cells below the capsule. Interiorly, spleen is represented by red and white pulp, veins, sinusoids and arteries.(fig $1,2 \& 3$ ). Sundaresan(2014), also reported the similar histological structures in the spleen of Tilapia mossambica. 


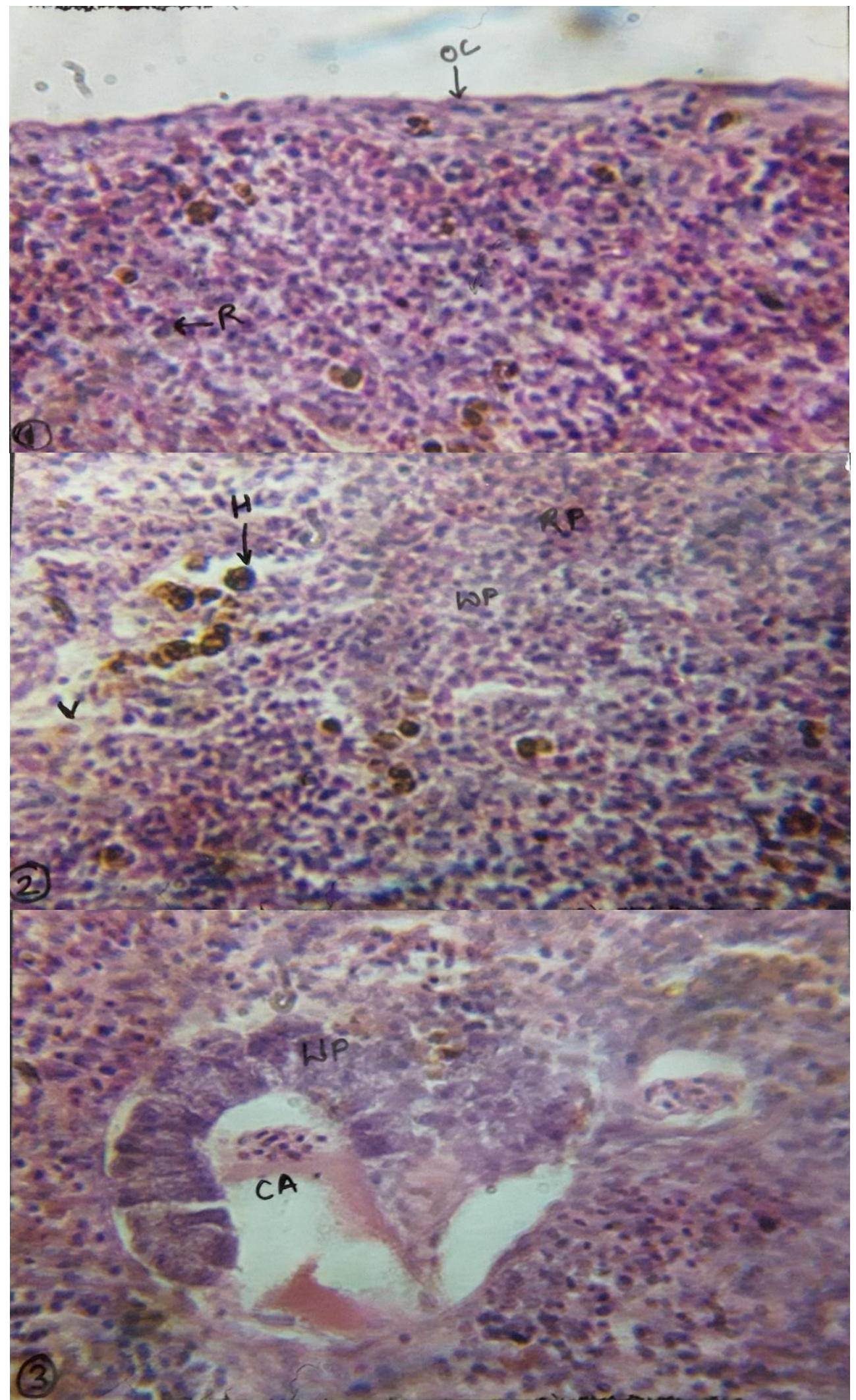

FIG 1,2 \&3:- Sections of spleen showing Normal architechture:Outer Capsule(OC), Red pulp (RP), White pulp (WP),Reticulocyte(R), Hemosiderin(H) and Central Artery(CA.) H \& E, 400X 


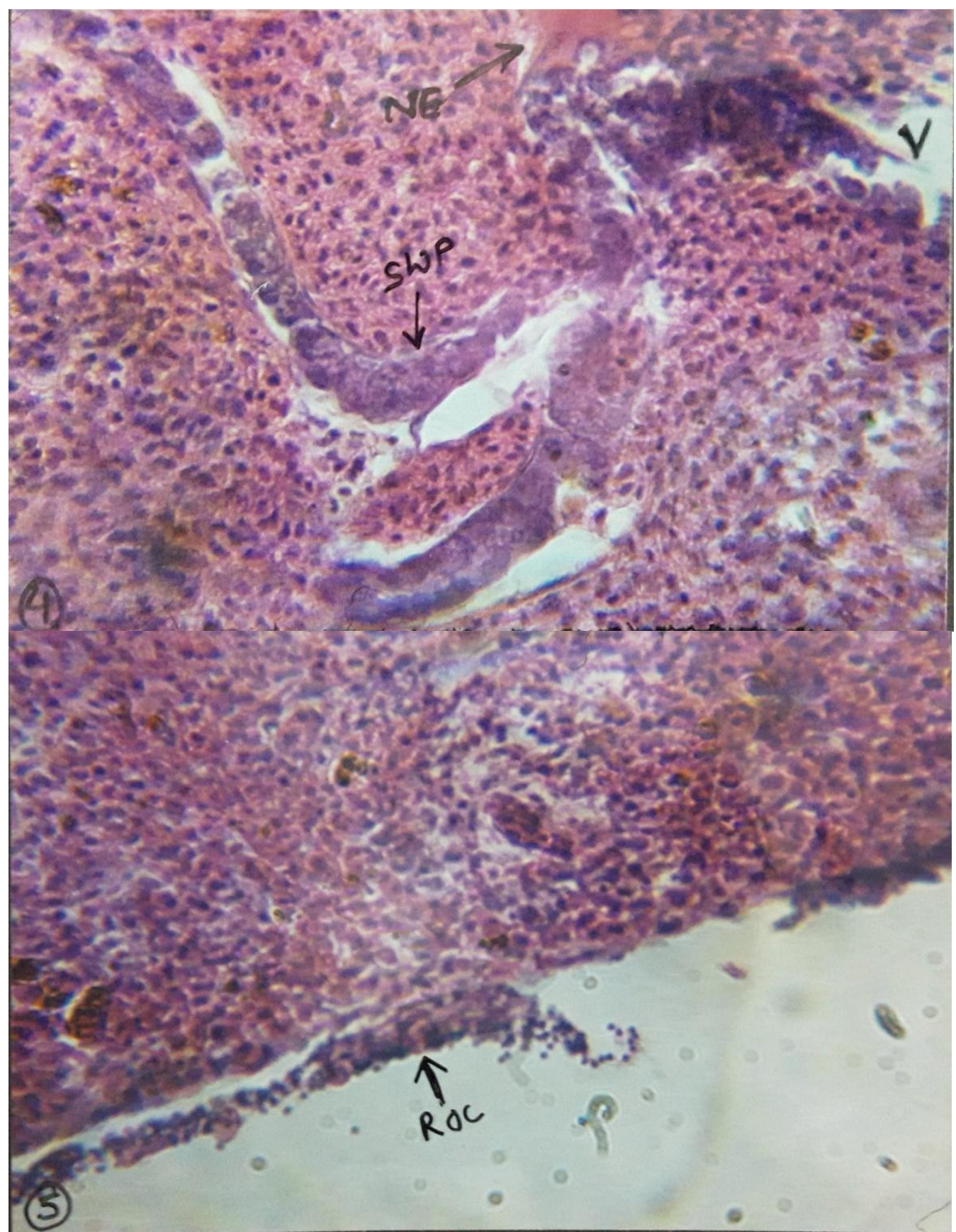

Fig 4\&5:- Section of spleen treated with 1/20 concentration showing :Ruptured Outer Capsule(ROC), Necrotic Eosinophils (NE), Scattered White pulp(SWP), and more Vacuolation (V) H \& E, 400X. 


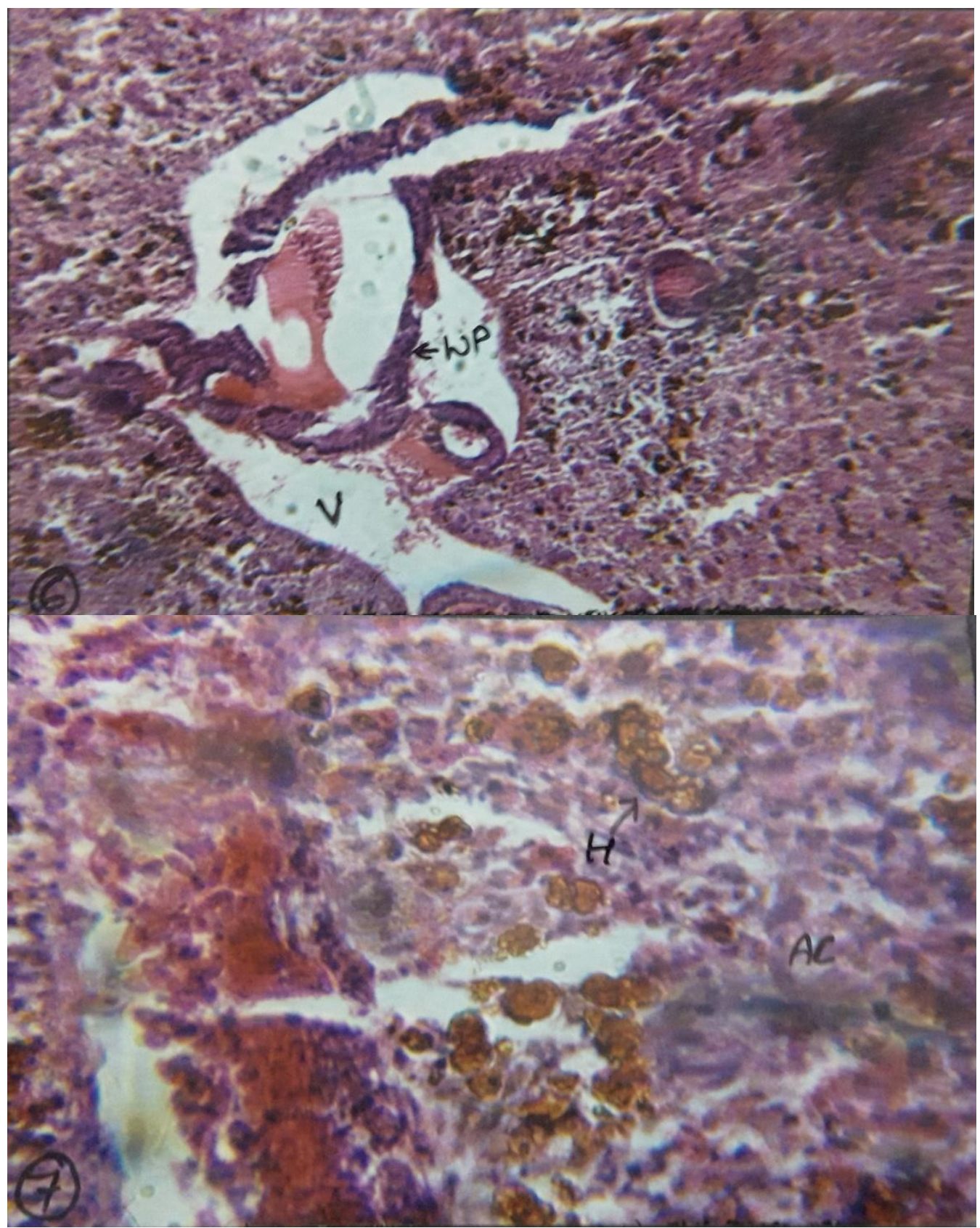

Fig 6\&7:- Section of spleen treated with 1/10 concentration showing :Anucleated cells(AC), Plenty of Hemosiderin(H), Degenerating White pulp(WP), and more Vacuolation (V) H \& E, 400X.

\section{Histopathology:-}

The histological investigations of the spleen in teleosts is mainly focused on the compartments that are important for the defense systems of the fishes; the lymphocytes and the macrophages (Fournie et al., 2001,Montero et al.,1999, Schmitt and Dethloff.,2000), and alterations in this organ caused by the presence of different toxicants in the environment (Garcia-Abiado et al., 2004).

The present histopathological studies revealed that when fishes were exposed to $1 / 20$ of LC50 value the major changes were noticed in the white pulp. The lymphocytes which were arranged in circular fashion around the central artery has scattered and there was no continuity(fig.4). Garcia-Abiado et al. (2004) mentioned that the presence of different toxicants in the environment caused alterations in fish spleen. Many vacuoles are seen in these cells. Nuclei also became less prominent. The outer capsule was found to be ruptured (fig.5). Necrosis, anucleated cells, large 
numbers of melanomacrophage centers and vacuolization in spleen tissues are associated with the toxicity of chlorpyrifos in the environment (Gogal et al., 1999).

When fishes were subjected to higher concentration of 1/15 then white pulp showed more degeneration. The erythrocytes became smaller in size and more vacuoles were observed in the stroma(fig.6). Takashima(1982) also reported that atrophy of the spleen is the common phenomenon which results in the decrease in number of erythrocytes. Large number of ruptures are seen and more yellowish brown stained granules are visible in the stroma of spleen showing heavy degradation of senescent erythrocytes(fig.7). Tayel et al. (2007, 2008) observed similar histopathological changes, as the findings of present study, in spleen of Oreochromis niloticus and Claria sgariepinus fishes.

Macrophages have been reported to digest phagocytosed erythrocytes leading to the deposition of hemosiderin with melanomacrophages (Naigaga, 2002). Under normal physiological conditions, the amount of hemosiderin is usually small but when large quantities are deposited they lead to a pathological condition known as hemosiderosis (Takashima, 1982.,David and Kartheek, 2015). In the present study also the amount of hemosiderin was increased as the concentration of CuSo4 was increased. The results of the present study of spleen hemosiderosis are in supportive with the findings of Khan et al. (1994) who reported hemosiderosis in the spleen of Pleuronectes americanus with a chronic content and exposure of heavy metals. Similar supportive findings were also reported by Fayhaa Salim (2015). The toxicity of any chemical is completely dependent on the concentration of the chemical to which an organisms is exposed (Ayoola, $2008 \mathrm{a} \& \mathrm{~b}$ ). The present study also revealed that with the increase in dose from $1 / 15$ to $1 / 10$ the major change observed was almost complete degeneration of white pulp. Vacuoles in the stroma were much more and very large in size. R.B.Cs completely lost their shape(fig $19 \& 20$ ).

\section{Conclusion:-}

The histopathological alterations observed in the spleen of fishes are due to the acute toxic effect of Copper Sulphate in Cyprinus carpio. The current result indicates that the heavy metal contamination definitely affect adversely to fish organs.

\section{References:-}

1. APHA (1995). Standard Methods for the Examination of Water and Waste Water, $19^{\text {th }}$ Edition, American Public Health Association, Washington DC.

2. Ayoola, S.O. (2008a).Toxicity of glyphosate herbicideon Nile tilapia (Oreochromisniloticus) juvenile. African

3. Journal of Agricultural Research, 3, 825-834.

4. Ayoola, S.O. (2008b). Histopathological effects ofglyphosate on juvenile African catfish (Clariasgariepinus).American-Eurasian Journal of Agricultural \& Environmental Science, 4, 362-367

5. Fayhaa Salim(2015).Histopathological Effect of heavy metal on different organs of fresh water fish tissues from Garmat Ali River adjacent to Al- Najebyia Power Station Kufa Journal For Veterinary Medical Sciences Vol. (6) No. (1) 2015

6. Fournie, J.W., J. Keven Summers, L.A. Courtney, V.D. Engle and V.S. Blazer, 2001. Utility of splenic macrophage aggregates as an indicator of fish exposure to degraded environments. Journal of Aquatic Animal Health, 13(2): 105-116.

7. Garcia-Abiado, M.A., G. Mbahinzireki, J. Rinchard, K.J. Lee and K. Dabrowski, 2004. Effect of diets containing gossypol on blood parameters and spleen structure in tilapia, Oreochromis sp., reared in a recirculating system. Journal of Fish Diseases, 27(6): 359-368.

8. Gogal, R. M., Smith, B. J., Robertson, J. L., Smith, S. A. and Holladay, S.D. (1999). Tilapia (Oreochromis niloticus) dosed with azathioprine display immune effects similar to those seen in mammals, including apoptosis. Veterinary Immunology and Immunopathology 68: 209-227.

9. Khan, R.A., D.E. Barker, R. Hooper, E.M. Lee, K. Ryan and K. Nag, 1994. Histopathology in winter flounder (Pleuronectes americanus) living adjacent to a pulp and paper mill. Archives of Environmental Contamination and Toxicology, 26(1): 95-102.

10. M. David and R.M. Kartheek (2015) Histopathological alterations in spleen of freshwater fish Cyprinus carpio exposed to sublethal concentration of sodium cyanide Open Veterinary Journal, Vol. 5(1): 1-5

11. Meenakshi Sundaresan(2014).Ultrastructure of Spleen in the Freshwater Fish, Tilapia mossambica (Peters)

12. EUROPEAN ACADEMIC RESEARCH - Vol. II, Issue 2 2894-2908 
13. Montero, D., Blazer, V.S., Socorro, J., Izquierdo, M. S., and L. Tort. Dietary and culture influences on macrophage aggregate parameters in gilthead seabream (Sparus aurata) juveniles. Aquaculture 1999, 179, 523534.

14. Naigaga, I., 2002. Bioaccumulation and histopathology of copper in Oreochromis mossambicus. M. Sc. Thesis (Ichthyology), Rhodes University, pp: XVI+124.

15. Raibeemol K.P and Chitra K.C.2015, Histopathological Alterations on Gill, Liver, Kidney and Spleen of Cichlid Fish, Etroplus maculatus Exposed To Chlorpyrifos. Int J Recent Sci Res. 6(10), pp. 6892-6896.

16. Roberts, R. Fish pathology, 3rd edition, (Ed.W. B. Saunders), 2001, 1-492. Churchill livingstone, USA Saad, S.M.M., A.E. El-Deeb, S.I. Tayel, E. Al-Shehri and N.A.M. Ahmed, (2012). Effect of heavy metals pollution on histopathological alterations in muscles of Clarias gariepinus inhabiting the Rosetta branch, River Nile, Egypt. 1st International Conference On Biotechnology Applications In Agriculture, Benha University, Moshtohor and Hurghada, 18-22, February 2012, Egypt, Animal Biotechnology, pp: 79-88

17. Schmitt, C. J. and G. M. Dethloff. Biomonitoring of environmental status and trends (BEST) program: selected methods for monitoring chemical contaminants and their effects in aquatic ecosystems, (Eds. U.S. Geological survey, biological resources division, Columbia). Information and technology report 2000, USGS/BRD- 20000005.

18. Singh NK, Verma MC, Munshi JSD (1990). Accumulation of Copper, Zinc, Lead, Iron and Cadmium in Certain Freshwater Fishes of River Subarnarekha. J. Fresh Wat. Biol., 2: 189-193.

19. Srivastava VMS, Tripathi RS, Saxena AK (1982). Changes in Gill of Punctius Sophore Under Chromium Stress. J. Biol. Res., 2: 85.

20. Takashima, F., 1982. Vascular system: spleen. pp. 62 - 64. In: Hibiya, T. (ed.), An atlas of fish histology: normal and pathological features. Kodasha Ltd. Tokyo.

21. Tayel, S.I., S.A. Ibrahim, M.M.N. Authman and M.A. El-Kasheif, 2007. Assessment of Sabal drainage canal water quality and its effect on blood and spleen histology of Oreochromis niloticus. African Journal of

22. Biological Sciences, 3(1): 97-107.

23. Tayel, S.I., A.M. Yacoub and S.A. Mahmoud, 2008. Histopathological and haematological responses to freshwater pollution in the Nile catfish Clarias gariepinus. Journal of Egyptian Academic Society forEnvironmental Development (D-Environmental Studies), 9(4): 43-60.

24. Tembhre,M. and Kumar,S.(1995),Acetylcholinesterase activity and enzyme kinetics in the gut of Cyprinus carpio subjected to acute and chronic exposure to copper. J. Ecobiol.,7(3):191-195.

25. Van der Oost R.; Beyer J. \& Vermeulen N.P.E. (2003). Fish bioaccumulation and biomarkers in environmental risk assessment: A review. Environ. Toxicol. Pharmacol., 13, 57-149. 